\title{
Kecepatan rigor mortis pada intoksikasi insektisida golongan organofosfat pada kelinci
}

\author{
Novianto Guanovora \\ Nola T. S. Mallo \\ Djemi Tomuka
}

\author{
${ }^{1}$ Kandidat Skripsi Fakultas Kedokteran Universitas Sam Ratulangi \\ ${ }^{2}$ Bagian Ilmu Kedokteran Forensik Medikolegal Fakultas Kedokteran \\ Universitas Sam Ratulangi - RSUP Prof. dr. R. D. Kandou Manado \\ Email: novianto.g.12303@gmail.com
}

\begin{abstract}
The objective of this study is to compare the time of rigor mortis formed between the control group and the treated group. This was a true experimental study with a post -test only control group design. This study was conducted at RSUP Prof. Dr. R. D. Kandou Forensic Laboratory Manado from September to November 2015. This research begins with caring of the rabbits (Oryctolagus cuniculus) weighting 1250 - 2100 g. were divided into two groups, control group and treated group. Treated group was exposed to diazinon 600 as many as $3 \mathrm{ml}$ in one treatment. Data were analyzed by using univariat analysis, subsequently tested by using independent $\mathrm{t}$-Test. The results showed that there was a significant difference ( $\mathrm{P}$ $<0.05$ ) in the time of rigor mortis formed and disappeared between the two groups. Conclusion: The time of rigor mortis formed and then disappeared was shorter among rabbits with organopgosphate intoxication compared to the ones without intoxication. Further studies are needed using instrument to evaluate the rigor mortis.
\end{abstract}

Keywords: rigor mortis, intoxication, organophosphate

\begin{abstract}
Abstrak: Penelitian ini bertujuan untuk membandingkan kecepatan rigor mortis pada kelompok kontrol dan kelompok perlakuan. Jenis penelitian eksperimental murni (true experimental desaign) dengan rancangan penelitian post test only control group desaign. Penelitian dilakukan dilaboratorium Forensik RSUP. Prof. Dr. dr. R. D. Kandou Manado pada bulan September - November 2015. Penelitian diawali dengan pemeliharaan kelinci (Oryctolagus Cuniculus ) dengan berat badan 1250 - 2100 g. Selanjutnya kelinci dibagi menjadi kelompok kontrol dan kelompok perlakuan, kelompok yang dilakukan pemaparan Diazinon 600 sebanyak $3 \mathrm{ml}$ dalam satu kali pemberian. Hasil penelitian menunjukkan terdapat perbedaan bemakna $(\mathrm{P}<0,05)$ waktu terbentuk rigor mortis, kaku, kaku sempurna, dan mulai melemas antara kelompok kontrol dan kelompok perlakuan. Simpulan: Waktu terbentuk rigor mortis dan waktu mulai melemas lebih singkat pada kelinci dengan intoksikasi organofosfat dibandingkan yang tanpa intoksikasi. Disarankan penelitian lebih lanjut dengan menggunakan alat ukur untuk menilai rigor mortis.
\end{abstract}

Kata kunci: rigor mortis, intoksikasi, organofosfat

Definisi Kematian menurut UndangUndang Republik Indonesia Nomor 36 Tahun 2009 Tentang Kesehatan, Pasal 117: "Seseorang dinyatakan mati apabila fungsi sistem jantung, sirkulasi dan sistem pernafasan terbukti telah berhenti secara permanen, atau apabila kematian batang otak telah dapat dibuktikan.”.Ilmu yang mempelajari tentang kematian dikenal dengan istilah Thanatologi. Thanatologi berasal dari kata thanatos yang berarti berhubungan dengan kematian dan logos 
yang berarti ilmu. Tanda-tanda kematian dibagi dua yaitu kematian pasti dan tidak pasti. Tanda kematian tidak pasti adalah penafasan berhenti, sirkulasi terhenti, kulit pucat, tonus otot menghilang dan relaksasi, pembuluh darah retina mengalami segmentasi dan pengeringan kornea. Sedangkan tanda pasti kematian adalah lebam mayat (livor mortis), kaku mayat (rigor mortis), penurunan suhu tubuh (algor mortis), pembusukan, mumifikasi dan adiposera. ${ }^{1}$ Dalam penelitian ini, yang ingin diketahui adalah Rigor Mortis.

Rigor mortis atau kaku mayat adalah salah satu tanda fisik kematian. rigor mortis dapat dikenali dari adanya kekakuan yang terjadi secara bertahap sesuai dengan lamanya waktu pasca kematian. ${ }^{2}$

Rigor Mortis terjadi akibat hilangnya adenosina trifosfat (ATP) dari otot-otot tubuh manusia. ATP digunakan untuk memisahkan ikatan aktin dan myosin pada otot sehingga otot dapat berelaksasi, dan hanya akan beregenerasi bila proses metabolisme terjadi, sehingga bila seseorang mengalami kematian, proses metabolismenya akan berhenti dan suplai ATP tidak akan terbentuk, sehingga tubuh perlahan-lahan akan menjadi kaku seiring menipisnya jumlah ATP pada otot. ${ }^{2}$

Toksikologi forensik merupakan salah satu cabang ilmu forensik yang mempelajari tentang zat kimia atau racun yang dapat mengancam hidup. Secara garis besar, toksikologi forensik mencakup terapan ilmu alam dalam menganalisis racun yang terlibat dalam tindak kriminal yang dituduhkan dan sebagai bukti tindak kriminal di pengadilan. Tujuan lain dari toksikologi forensik ialah untuk mendeteksi dan mengidentifikasi konsentrasi dari zat racun dan metabolitnya dalam materi biologi serta mengintepretasikan temuan analisis dalam suatu argumentasi tentang penyebab keracunan. ${ }^{3}$

Menurut World Health Organization (WHO), satu juta kasus keracunan berat dan dua juta kasus bunuh diri menggunakan organofosfat terjadi di seluruh dunia dan 200.000 diantaranya meninggal. ${ }^{4}$ WHO memperkirakan kejadian keracunan insektisida akut sebanyak 3.000.000 kasus setiap tahunnya dengan angka kematian sejumlah 220.000 kasus. Mayoritas insiden ini terjadi di negaranegara berkembang, terutamadi Afrika, Asia, Amerika tengah dan Amerika Selatan. Peningkatan insiden bermakna di Amerika Tengah terjadi dari tahun 1992 sampai tahun 2000 dengan angka kejadian keracunan insektisida meningkat dari 6,3 per 100.000 populasi menjadi 19,3 per 100.000 populasi dengan kecepatan mortalitas yang meningkat dari 0,3 per 100.000 populasi menjadi 2,1 per 100.000 kasus. $^{5}$ Berdasarkan laporan dari Mabes Polri pada tahun 2012 ditemukan bahwa angka bunuh diri dengan organofosfat sekitar $0.5 \%$ dari 100.000 populasi, yang berarti ada sekitar 1.170 kasus bunuh diri yang dilaporkan dalam satu tahun. ${ }^{3}$

Insektisida sendiri adalah racun serangga yang banyak dipakai dalam pertanian, perkebunan, dan dalam rumah tangga. Keracunan insektisida biasanya terjadi karena kecelekaan dan percobaan bunuh diri, jarang sekali karena pembunuhan. Insektisida digolongan dalam hidrokarbon terkhlorinasi dan inhibitor kolinesterase (organofosfat dan karbamat). ${ }^{2}$ Pada penelitian ini, peneliti menggunakan insektisida golongan inhibitor kolinesterase yaitu organofosfat. Karena ketersediaannya dalam kehidupan sehari-hari dan gampang ditemukan di pasar atau minimarket setempat. Insiden kasus bunuh diri dengan menggunakan organofosfat semakin meningkat. ${ }^{5}$

Dalam penelitian ini digunakan hewan coba yaitu kelinci yang sehat karena kelinci memiliki kemampuan untuk hidup dan berkembangbiak dengan baik dalam habitat yang bervariasi mulai dari padang pasir, daerah subtropis dan daerah tropis. Kelinci mudah beradaptasi terhadap bentuk kandang yang beraneka ragam dari yang paling sederhana di bawah kolong tanah/rumah panggung sampai model kandang modern. ${ }^{6}$

Berdasarkan tingginya insiden bunuh diri dengan menggunakan insektisida golongan organofosfat secara oral, 
penelitian ini bertujuan mengetahui seberapa cepat kelompok terjadinya rigor mortis tanpa perlakuan dan dengan perlakuan pemberian organofosfat.

\section{Rigor mortis}

Rigor mortis atau kaku mayat adalah salah satu tanda fisik kematian. Rigor mortis dapat dikenali dari adanya kekakuan yang terjadi secara bertahap sesuai dengan lamanya waktu pasca kematian. ${ }^{2}$

Rigor mortis terjadi akibat hilangnya adenosina trifosfat (ATP) dari otot-otot tubuh manusia. ATP digunakan untuk memisahkan ikatan aktin dan myosin pada otot sehingga otot dapat berelaksasi, dan hanya akan beregenerasi bila proses metabolisme terjadi, sehingga bila seseorang mengalami kematian, proses metabolismenya akan berhenti dan suplai ATP tidak akan terbentuk, sehingga tubuh perlahan-lahan akan menjadi kaku seiring menipisnya jumlah ATP pada otot. ${ }^{2}$ Secara Fisiologi ATP baru berguna untuk melekat pada myosin agar iktan jembatan silang antara myosin dan aktin dapat terlepas pada akhir siklus, meskipun selama proses disosiasi ini ATP tidak terurai. Kebutuhan akan ATP dalam memisahkan myosin dan aktin jelas terlihat dalam rigor mortis (kaku mayat), suatu penguncian menyuluruh otot rangka yang dimulai 3 sampai 4 jam setelah kematian, konsentrasi $\mathrm{Ca}^{2+}$ sitosol mulai meningkat, kemungkinan besar karena membran sel otot inaktif tidak dapat menahan $\mathrm{Ca}^{2+}$ esktrasel dan juga mungkin karena $\mathrm{Ca}^{2+}$ keluar dari kantung lateral. $\mathrm{Ca}^{2+}$ ini menggeser samping protein-protein regulatorik, menyebabkan aktin berikatan dengan jembatan silang myosin, yang sudah dibekali ATP sebelum kematian. Sel sel mati tidak lagi dapat menghasilkan ATP sehingga aktin dan myosin, sekali terikat, tidak dapat terlepas. karena sel-sel tersebut tidak memiliki ATP segar. Karena itu filamen tipis dan tebal tetap terikat oleh jembatan silang, menyebabkan otot yang mati menjadi kaku. Dalam beberapa hari selanjutnya, kaku mayat secara bertahap berkurang akibat protein-protein yang terlibat dalam kompleks rigor mortis mulai terurai. ${ }^{7,8}$

Ikatan antara aktin dan myosin di otot manusia akan menetap (menggumpal) dan terjadilah kekakuan jenazah. Rigor mortis akan mulai muncul 2 jam postmortem (setelah kematian). Ciri fisik akan semakin dapat teridentifikasi hingga mencapai mencapai titik maksimal pada 12 jam postmortem. Namun setelah itu, ciri ini akan berangsur-angsur menghilang sama seperti dengan kemunculannya. Pada 12 jam setelah kekakuan maksimal (24 jam postmortem) kaku jenazah sudah tidak ada lagi. Faktor-faktor yang memengaruhi terjadinya kaku jenazah adalah suhu tubuh, volume otot dan suhu lingkungan. Makin tinggi suhu tubuh makin cepat terjadi kaku jenazah. Rigor mortis diperiksa dengan cara menggerakkan sendi fleksi dan antefleksi pada seluruh persendian tubuh. ${ }^{2}$

Hal-hal memiliki tanda fisik sama namun berbeda dari rigor mortis atau kaku jenazah adalah:

1. Cadaveric Spasmus, yaitu kekakuan otot yang terjadi pada saat kematian dan menetap sesudah kematian akibat hilangnya ATP lokal saat mati karena kelelahan atau emosi yang hebat sesaat sebelum mati.

2. Heat stiffening, yaitu kekakuan otot akibat koagulasi protein karena panas sehingga serabut otot memendek dan terjadi flexi sendi. Misalnya pada mayat yang tersimpan dalam ruangan dengan pemanas ruangan dalam waktu yang lama.

3. Cold stiffening, yaitu kekakuan tubuh akibat lingkungan yang dingin sehingga terjadi pembekuan cairan tubuh dan pemadatan jaringan lemak pada lapisan subkutan sampai otot. ${ }^{2}$

\section{Keracunan dan Jalan Masuk Racun}

Keracunan merupakan masuknya suatu zat ke dalam tubuh yang dapat mengakibatkan gangguan kesehatan serta kematian.Keracunan akibat insektisida sudah menjadi masalah seluruh dunia.Estimasi jumlah kasus per tahun sebesar 1-3 juta. Angka kematian beragam mulai dari $1 \%$ sampai $9 \%$ kasus yang 
datang berobat, dan bergantung pada ketersediaan antidote serta mutu layanan medis yang diberikan. Keracunan yang disengaja (terutama untuk upaya percobaan bunuh diri atau berhasil bunuh diri), proporsinya dalam kasus keracunan insektisida cukup besar di Negara tertentu. ${ }^{9}$

Jalur masuk atau portal entri adalah pintu masuknya xenobiotik ke dalam tubuh organisme. Xenobiotik merupakan bahan asing bagi tubuh organisme; racun. ${ }^{10}$

Racun masuk ke dalam tubuh melalui berbagai cara yaitu ${ }^{10}$ :

1. Ditelan (per oral; ingesti)

Portal entri ini sering dan mudah terjadi namun bahan asing yang masuk tidak akan mudah mencapai peredaran darah karena beberapa hal penting yang terkait pada fungsi saluran gastro intestinal. Di mulut xenobiotik bercampur dengan ludah yang mengandung enzim, di dalam lambung xenobiotik yang tidak tahan asam akan dihancurkan oleh asam lambung, di usus halus akan bertemu dengan enzim usus halus yang bersifat basa sehingga xenobiotik asam akan ternetralisir, dan seterusnya hingga terbuang melalui usus besar. Proses absorpsi terjadi melalui mukosa usus, yang selanjutnya mengalir melalui system sirkulasi darah. $^{4}$

2. Terhisap bersama udara pernafasan (inhalasi)

Bukti mengenai efek yang serius akibat pajanan melalui udara terhadap kesehatan manusia masih sangat sedikit. $^{7,8}$

3. Melalui penyuntikan (parenteral, injeksi)

4. Penyerapan melalui kulit (absorpsi) Pajanan xenobiotik melalui kulit terjadi ketika xenobiotik tumpah mengenai kulit atau terbawa angin hingga menempel ke kulit. Semakin luas area kulit yang terkena dan semakin lama durasi kontak maka semakin serius dampak yang akan terjadi. Pajanan melalui absorpsi dermal dapat dikurangi secara signifikan dengan penggunaan pakaian pelindung. ${ }^{4}$ Toksisitas melalui kulit (acute dermal toxicity) dapat terjadi jika xenobiotik diabsorpsi kulit dapat menembus epidermis, kemudian memasuki kapiler darah dalam kulit, sehingga terbawa sampai paru-paru dan organ vital lainnya seperti otak dan otot. ${ }^{7}$ Xenobiotik akan segera diabsorpsi jika kontak melalui kulit atau mata. Absorpsi ini akan terus berlangsung selama pestisida masih ada pada kulit. Kecepatan absorpsi berbeda pada tiap bagian tubuh. Perpindahan residu pestisida akan menambah potensi keracunan. Residu dapat berpindah dari tangan ke dahi yang berkeringat atau daerah genital. Pada daerah ini kecepatan absorpsi sangat tinggi sehingga dapat lebih berbahaya daripada tertelan. ${ }^{11}$

5. Melalui anus atau vagina (perektal, pervaginam)

\section{Insektisida}

Insektisida adalah racun serangga yang banyak dipakai dalam pertanian, perkebunan, dan dalam rumah tangga. Keracunan insektisida biasanya terjadi karena kecelekaan dan percobaan bunuh diri, jarang sekali karena pembunuhan. Insektisida digolongan dalam hidrokarbon terkhlorinasi dan inhibitor kolinesterase (organofosfat dan karbamat). Hidrokarbon terkhlorinasi adalah zat kimia sintetik yang stabil beberapa minggu sampai beberapa bulan setelah penggunaannya. ${ }^{2}$ Pada penelitian ini, penulis menggunakan insektisida golongan inhibitor kolinesterase dalam hal ini organofosfat.

Organofosfat memiliki struktur kimia dengan atom oksigen atau sulfur yang berikatan ganda dengan fosfor, sehingga disebut phosphate atau phosphorothioates. ${ }^{11}$ Lebih dari 50.000 komponen organophosphate telah disynthesis dan diuji untuk aktivitas insektisidanya. Tetapi yang telah digunakan tidak lebih dari 500 jenis saja. Semua produk organophosphate tersebut berefek toksik bila tertelan, dimana hal ini sama dengan tujuan penggunaannya untuk membunuh serangga. ${ }^{4}$ Sebagian 
besar senyawa organofosfat berikatan sulfur, karena bentuk $\mathrm{P}=\mathrm{S}$ lebih stabil dan larut lemak. ${ }^{11}$

Organophosphat adalah insektisida yang paling toksik diantara jenis insektisida lainnya dan sering menyebabkan keracunan pada orang. Termakan hanya dalam jumlah sedikit saja dapat menyebabkan kematian, tetapi diperlukan lebih dari beberapa mg untuk dapat menyebabkan kematian pada orang dewasa. Organofosfat menghambat aksi pseudokholinesterase dalam plasma dan kholinesterase dalam sel darah merah dan pada sinapsisnya. Enzim tersebut secara normal menghidrolisis asetilkolin menjadi asetat dan kholin. Pada saat enzim dihambat, mengakibatkan jumlah asetilkolin meningkat dan berikatan dengan reseptor muskarinik dan nikotinik pada system saraf pusat dan perifer. Hal tersebut menyebabkan timbulnya gejala keracunan yang berpengaruh pada seluruh bagian tubuh. ${ }^{5}$

Pada insektisida golongan organofosfat, ada organofosfat dengan inhibisi langsung (yang mengandung $=\mathrm{O}$ ) dan organofosfat dengan inhibisi tak langsung (yang mengandung $=S$ ) tergantung dari dibutuhkan atau tidaknya pengaktivan metabolik sebelum terjadinya hambatan pada asetilkolineseterase. Dengan kata lain, senyawa organofosfat indirek harus menjalani bioaktivasi sehingga menjadi aktif secara biologi. Senyawa organofosfat indirek contohnya parathion, diazinon, malathion, dan chlorpyrifos menjadi lebih toksik dibandingkan senyawa induknya. ${ }^{8}$

Penghambatan kerja enzim terjadi karena organophosphate melakukan fosforilasi enzim tersebut dalam bentuk komponen yang stabil. Asetilkolin (ACh) adalah penghantar saraf yang berada pada seluruh sistem saraf pusat (SSP), saraf otonom (simpatik dan parasimpatik), dan sistem saraf somatik. Asetilkolin bekerja pada ganglion simpatik dan parasimpatik, reseptor parasimpatik, simpangan saraf otot, penghantar sel-sel saraf dan medula kelenjar suprarenal. Setelah masuk dalam tubuh, golongan organofosfat akan mengikat enzim asetilkolinesterase
(AChE), sehingga AChE menjadi inaktif dan terjadi akumulasi asetilkolin. Enzim tersebut secara normal menghidrolisis asetilkolin menjadi asetat dan kolin. Pada saat enzim dihambat, mengakibatkan jumlah asetilkolin meningkat dan berikatan dengan reseptor muskarinik dan nikotinik pada system saraf pusat dan perifer. Hal tersebut menyebabkan timbulnya gejala keracunan yang berpengaruh pada seluruh bagian tubuh. Keadaan ini akan menimbulkan efek yang luas. ${ }^{7}$ kematian karena organofosfat disebabakan oleh kegagalan pernapasan, karena diafragma tidak dapat mengalami repolarisasi dan kembali kekeadaan istirahatnya, kemudian berkontraksi ulang membawa masuk udara segar.

Organofosfat menghambat aksi pseudokolinesterase dalam plasma dan kolinesterase dalam sel darah merah dan pada sinapsisnya. Penghambatan kerja enzim terjadi karena organofosfat melakukan fosforilasi enzim tersebut dalam bentuk komponen yang stabil. Potensiasi aktivitas parasimpatik post-ganglionik, mengakibatkan kontraksi pupil, stimulasi otot saluran cerna, stimulasi saliva dan kelenjar keringat, kontraksi otot bronkial, kontraksi kandung kemih, nodus sinus jantung dan nodus atrio-ventrikular dihambat. Mula-mula stimulasi disusul dengan depresi pada sel sistem saraf pusat (SSP) sehingga menghambat pusat pernafasan dan pusat kejang. Stimulasi dan blok yang bervariasi pada ganglion dapat mengakibatkan tekanan darah naik atau turun serta dilatasi atau miosis pupil. Kematian disebabkan karena kegagalan pernafasan dan blok jantung. ${ }^{7,11}$

\section{Hubungan Kecepatan Rigor mortis dengan Keracunan Organofosfat}

Dalam proses taut neuromuskular, sel saraf dan sel otot sebenarnya tidak berkontak satu samalin. Ruang atau celah antara keduanya terlalu besar untuk memungkinkan transmisi listrik suatu impuls antara keduanya. Selain itu tidak terdapat saluran keluar bagi arus pembawa muatan dari terminal button (terminal 
akson yang membesar membentuk struktur mirip tombol). Karenanya, seperti disinaps saraf terdapat suatu pembawa pesan kmimiawi yang mengangkut sinyal antara ujung saraf dan serat otot. Neurotarnsmiter ini disebut asetilkolin (ACh). Setiap terminal buton mengandung ribuan vesikel yang menyimpan ACh. Perambatan potensial aksi ke terminal akson memicu pembukaan saluran $\mathrm{Ca}^{2+}$ berpintu tegangan di terminal button. Pembukaan saluran $\mathrm{Ca}^{2+}$ memungkinkan $\mathrm{Ca}^{2+}$ berdifusi kedalam terminal button dari konsentrasi ekstraselnya yang lebih tinggi, yang pada gilirannya menyebabkn pelepasan ACh melalui eksositosis dari beberapa ratus vesikel ke dalam celah. ACh yang disebabkan berdifusi melintasi celah dan berikatan dengan reseptor spesifik, yaitu protein membran khusus yang khas bagi bagian motor end plate (neuromuskular) membrane serat otot (tahap kolinergik ini adalah tipe nikotinik). Pengikatan ACh dengan resptor ini memicu pembukaan saluran berpintu kimiawi di motor end plate. Saluran ini memungkinkan sejumlah kecil kation berpindah melewatinya (baik $\mathrm{Na}^{+}$maupun $\mathrm{K}^{+}$) tetapi tidak untuk anion. Karena permeabilitas memebran motor end plate. Saluran terhadap $\mathrm{Na}^{+}$maupun $\mathrm{K}^{+}$. pada pembukaan saluran-saluran ini pada hakikatnya sama, maka perpindahan relative ion-ion ini melalui saluran bergantung pada gaya dorong elektrokimiawi mereka. ${ }^{7,8}$

Organofosfat memodifikasi aktifitas taut motor end plate dengan cara menghambat secara irreversible AChE. AChE menghambat inaktivasi ACh yang telah dibebaskan. ${ }^{7,8}$ Dalam mekanisme organofosfat AChE dihambat sehingga tidak terjadi pembersihan ACh yang seharusnya AChE berfungsi mengakhiri aktivitas ACh di taut motor end plate. Pembersihan ACh mengakhiri end plate potensial (EPP) sehingga membran sel otot kembali ke potensial istirahat (otot dalam keadaan relaksasi). Jika terjadi hambatan AChE pada keracunan organofosfat maka terjadi peningkatan ACh pada taut motor end plate dan terjadi kontraksi otot terus menerus. Berkelanjutannya kontraksi otot ini menyebabakan deplesi dari ATP (adenosine tripohospat) pada otot sehingga terjadi penggumpalan pada aktin dan myosin membuat terjadinya kekakuan pada otot. Dalam kasus ini keracunan insektisida golongan organofosfat menyebabkan peningkatan kecepatan rigor mortis dan dimana terjadinya deplesi ATP dan peningkatan reseptor ACh sehingga kontraksi otot terjadi secara terus menerus (tanpa relaksasi). ${ }^{7,8,12-15}$

Keracunan terjadi gangguan degenerasi pada sel saraf otak yang disebabkan oleh organofosfat dapat terjadi karena proses nekrosis dan apoptosis. Proses nekrosis dimulai dengan adanya inhibisi kolinesterase yang akan menyebabkan asetilkolin tertimbun di sinaps sehingga terjadi stimulasi yang terus-menerus pada reseptor postsinaptik. Overstimulasi pada reseptor muskarinik dan nikotinik menyebabkan timbulnya efek kolinergik. Adanya akumulasi asetilkolin ini juga akan menyebabkan aktivasi neuron glutamatergik yang memicu aktivasi reseptor NMDA ( $N$-methyl-D-aspartate) dan ditandai dengan pembukaan saluran ion kalsium pada celah sinaps. Pembukaan saluran ion ini mengakibatkan influks ion $\mathrm{Ca} 2+$ besarbesaran pada postsinaps dan memicu terjadinya proses neurodegenerasi pada otak. Neurodegenerasi sel akibat toksisitas kronik dari organofosfat disebabkan karena proses kematian sel dan apoptosis yang dipicu oleh adanya penumpukan radikal bebas (ROS; reactive oxygen species). Keracunan organofosfat dapat menyebabkan terjadinya kerusakan mitokondria yang mengakibatkan penumpukan radikal bebas dan timbulnya stress oksidatif. Adanya radikal bebas tersebut memicu deplesi ATP, menginduksi pengeluaran enzim proteolitik, menyebabkan fragmentasi DNA, yang akhirnya mengakibatkan terjadinya kematian sel. ${ }^{12-14,17}$

Kerusakan pada sel saraf pusat juga dapat disebabkan oleh OPIDN (organophosphorus ester-induced delayed neurotoxicity) yaitu neurodegenerasi dengan lesi aksonopati distal pada sistem 
saraf pusat dan perifer. ${ }^{12}$

Terjadinya kematian sel dan deplesi ATP karena proses dari peningkatan dari Asetilkolin. Kemudian terjadi Reaksi Hidrolisis Asetilkolin Menjadi Asetat dan Kolin. ${ }^{7}$ Dalam reaksi siklus krebs, asam laktat meningkat maka terjadinya reaksi anaerob, ${ }^{7,8}$ Jika ATP habis dari setiap cadangan yang disimpan, yang dibutuhkan untuk pemisahan jembatan silang dari filament aktin selama proses relaksasi sehingga terjadinya rigor mortis. Otot akan kaku sampai protein-protein terurai. ${ }^{18}$

\section{METODE PENELITIAN}

Penelitian ini menggunakan metode eksperimental murni (true experimental design) dengan rancangan penelitian post test only control group design. Penelitian ini dilakukan di Laboratorium Forensik Fakultas Kedokteran Universitas Sam Ratulangi RSUP Prof. Dr. dr. R. D. Kandou Manado pada bulan September - November 2015. Objek penelitian ialah kelinci spesies Oryctolagus cuniculus dewasa, sehat, berumur 16-18 minggu dengan berat badan 1000-2100 g. Kelinci yang memenuhi kriteria dibagi menjadi dua kelompok, masing-masing kelompok terdiri dari lima ekor kelinci kelompok control dan lima ekor kelinci kelompok perlakuan. Pada kelompok kelinci pertama sebagai kontrol dimatikan dengan cara deserebrasi. Pada kelompok kelinci kedua diberikan secara oral organofosfat dengan dosis $3 \mathrm{ml}$ dan diamati keadaan kelinci sampai terjadi kematian dan terjadi kekakuan.

\section{HASIL PENELITIAN}

Setiap kelompok diamati mulai dari waktu kematian, terbentuk rigor mortis, sampai mulai melemas. Hasil yang didapatkan menunjukkan rerata waktu terbentuk rigor mortis dari keseluruhan sampel adalah 46,20 menit, rerata waktu rigor mortis sempurna dari keseluruhan sampel adalah 292,50 menit, dan rerata waktu mulai melemas dari keseluruhan sampel adalah 539,00 menit. Variabel dari seluruh sampel menurut berat badan, waktu terbentuk rigor mortis, waktu rigor mortis sempurna, dan waktu melemas dapat dilihat pada Tabel 1.

Perbandingan Waktu Terbentuk Rigor
Mortis, Waktu Terbentuk Rigor Mortis
Sempurna, Serta Waktu Mulai Melemas
Antara Kelompok Kontrol Dan
Kelompok Perlakuan

Pada kelompok kontrol dan kelompok perlakuan didapatkan nilai rerata waktu terbentuk rigor mortis masing-masing 63,40 menit dan 29,00 menit. Hasil uji T menunjukkan terdapat perbedaan bermakna waktu terbentuk rigor mortis antara kedua kelompok dengan nilai $p=0,000 \quad(p<0,05)$ (Tabel 2).

Pada kelompok kontrol dan kelompok perlakuan didapatkan nilai rerata waktu terbentuk rigor mortis sempurna masingmasing 340,80 menit dan 244,80 menit. Hasil uji $\mathrm{T}$ menunjukkan terdapat perbedaan bermakna waktu terbentuk rigor mortis antara kedua kelompok dengan nilai $p=0,000(p<0,05)$ (Tabel 3).

Pada kelompok kontrol dan kelompok perlakuan didapatkan nilai rerata waktu terbentuk mulai melemas masing-masing 600,20 menit dan 469,20 menit. Hasil uji T menunjukkan terdapat perbedaan bermakna waktu terbentuk rigor mortis antara kedua kelompok dengan nilai $p=0,000 \quad(p<0,05)$ (Tabel 4).

Berdasarkan hasil uji normalitas dan uji homogenitas didapatkan bahwa data seluruh variabel penelitian terdistribusi normal dan memiliki varian yang sama dimana masing-masing memiliki signifikansi $\leq 0,05$. Oleh karena itu untuk uji hipotesis secara statistik digunakan metode pengujian parametrik uji T-test Independent Sample. Pengujian menggunakan T-Test, diperoleh angka nilai T hitung 50,70 pada waktu terbentuk rigor mortis, waktu terbentuk rigor mortis sempurna nilai $\mathrm{T}$ hitung 14,729 , serta waktu mulai melemas 22,046 didapatkan T hitung > dari $\mathrm{T}$ tabel yang hipotesis 0 (H0) diterima dengan kesimpulan terdapat perbedaan signifikan waktu terbentuk rigor mortis, waktu terbentuk rigor mortis sempurna, serta waktu mulai melemas pada 
intoksikasi organofosfat antara kelompok kontrol dan kelompok perlakuan. Pengujian menggunakan T-Test, diperoleh angka nilai 0,000 pada waktu terbentuk rigor mortis, waktu terbentuk rigor mortis sempurna, serta waktu mulai melemas didapatkan $\mathrm{P}$ Value (Asymp. Sig.2-tailed) < 0, hipotesis null (H0) diterima dengan kesimpulan terdapat perbedaan signifikan waktu waktu terbentuk rigor mortis, waktu terbentuk rigor mortis sempurna, serta waktu mulai melemas pada intoksikasi organofosfat antara kelompok kontrol dan kelompok perlakuan.

Tabel 2. Karakteristik seluruh sampel

\begin{tabular}{|c|c|c|c|}
\hline Variabel & $n(\%)$ & $\begin{array}{l}\text { Mean } \pm S \\
\text { D }\end{array}$ & $\begin{array}{c}\text { Median } \\
\text { (min-max) }\end{array}$ \\
\hline Kelompok & $5(50$ & - & - \\
\hline Kontrol & $\%)$ & & \\
\hline Kelompok & $5(50$ & - & - \\
\hline Perlakuan & $\%)$ & & \\
\hline BB (gram) & - & $\begin{array}{c}1560 \pm 22 \\
3,358\end{array}$ & $\begin{array}{c}1500(1250- \\
2100)\end{array}$ \\
\hline $\begin{array}{l}\text { Waktu terbentuk } \\
\text { rigor mortis } \\
\text { (menit) }\end{array}$ & - & $\begin{array}{c}46,20 \pm 18 \\
, 159\end{array}$ & $\begin{array}{c}46.00(28- \\
65)\end{array}$ \\
\hline $\begin{array}{l}\text { waktu rigor } \\
\text { mortis sempurna }\end{array}$ & - & $292,80 \pm 5$ & $296,50(231$ \\
\hline $\begin{array}{l}\text { (menit) } \\
\text { waktu mulai }\end{array}$ & - & 1,521 & $-351)$ \\
\hline melemas (menit) & - & $\begin{array}{c}534,70 \pm 6 \\
9,610\end{array}$ & $\begin{array}{l}539,00(455 \\
-603)\end{array}$ \\
\hline
\end{tabular}

Keterangan: $\mathrm{n}$ = jumlah sampel,

$\mathrm{SD}=$ Standard Deviation, $\mathrm{BB}=$ Berat Badan

Tabel 3. Perbandingan waktu terbentuk rigor mortis antara kelompok kontrol dan kelompok perlakuan

\begin{tabular}{lcc}
\hline & \multicolumn{2}{c}{$\begin{array}{c}\text { Waktu Terbentuk rigor mortis } \\
\text { (menit) }\end{array}$} \\
\cline { 2 - 3 } & Kontrol & Perlakuan \\
\hline Mean & 63,40 & 29,00 \\
Median & 63,00 & 29,00 \\
SD & 1.140 & 1,000 \\
Min-Max & $62-65$ & $28-30$ \\
\hline \multicolumn{3}{c}{$p=0,000$} \\
\hline
\end{tabular}

Keterangan : SD = Standard Deviation
Tabel 4. Perbandingan waktu rigor mortis sempurna antara kelompok kontrol dan kelompok perlakuan

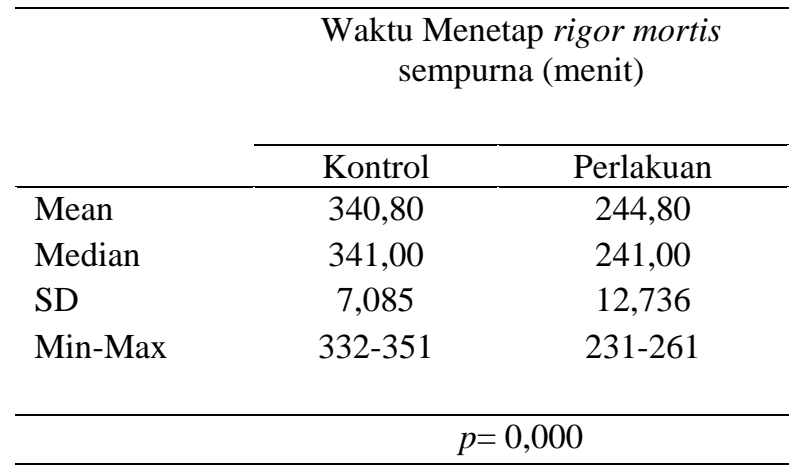

Keterangan : SD = Standard Deviation

Tabel 5. Perbandingan waktu mulai melemas antara kelompok kontrol dan kelompok perlakuan

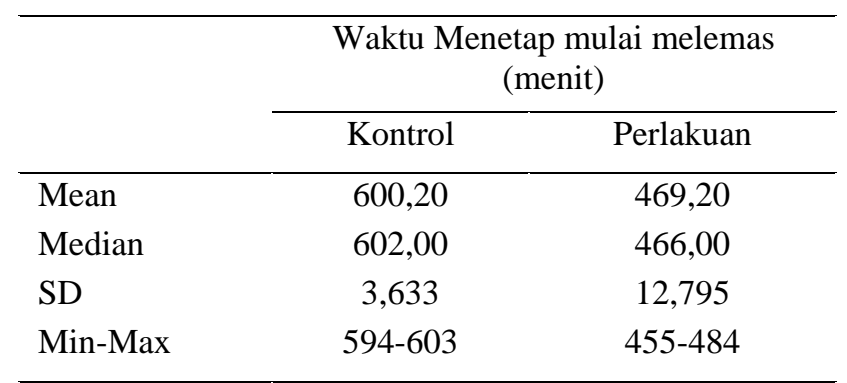

Keterangan : SD = Standard Deviation

\section{BAHASAN}

Pada penelitian ini ditemukan bahwa rerata waktu terbentuk rigor mortis pada kelompok kontrol (63,40 menit) lebih lama daripada kelompok perlakuan (29 menit), secara statistik terdapat perbedaan yang bermakna $(p<0,05$ atau $p=0,000)$. Penilitian ini juga menemukan bahwa rerata waktu terbentuknya rigor mortis dan rigor mortis sempurna pada kelompok kontrol (249 menit) dan (341 menit), lebih cepat daripada kelompok perlakuan (149 menit) dan (241 menit). Hal ini menunjukkan bahwa terdapat perbedaan waktu terbentuk rigor mortis antara kelompok kontrol (kelinci yang tidak diberikan) dengan kelompok perlakuan (kelinci yang diberikan organofosfat).

Secara fisiologi ATP baru berguna untuk melekat pada myosin agar iktan jembatan silang antara myosin dan aktin 
dapat terlepas pada akhir siklus, meskipun selama proses disosiasi ini ATP tidak terurai. Kebutuhan akan ATP dalam memisahkan myosin dan aktin jelas terlihat dalam rigor mortis (kaku mayat). ${ }^{7,8}$ Ikatan antara aktin dan myosin di otot manusia akan menetap (menggumpal) dan terjadilah kekakuan jenazah. Rigor mortis akan mulai muncul 2 jam postmortem (setelah kematian). ${ }^{2}$ Pemberian organofosfat pada kelinci perlakuan maka mempercepat terjadinya rigor mortis, ini dikarenakan kerja dari organofosfat Dalam mekanisme organofosfat AChE dihambat sehingga tidak terjadi pembersihan ACh yang seharusnya AChE berfungsi mengakhiri aktivitas ACh di taut motor end plate. Pembersihan ACh mengakhiri end plate potensial (EPP) sehingga membran sel otot kembali ke potensial istirahat (otot dalam keadaan relaksasi). Jika terjadi hambatan AChE pada keracunan organofosfat maka terjadi peningkatan ACh pada taut motor end plate dan terjadi kontraksi otot terus menerus. Pada kelinci, rigor mortis yang terbentuk lebih cepat dibandingkan manusia kemungkinan oleh karena luas penampang tubuh kelinci yang lebih kecil dibandingkan manusia sehingga darah lebih cepat terakumulasi di pembuluh darah kecil di bagian tubuh yang paling rendah. ${ }^{7,8,19}$

Hasil penelitian ini (tabel menunjukkan bahwa kisaran waktu rigor mortis terbentuk pada kelompok kontrol (62 - 65 menit) lebih lama dibandingkan dengan kisaran waktu terbentuk rigor mortis pada kelompok perlakuan yang mati akibat intoksikasi organofosfat (28-30 menit). Hal ini kemungkinan karena efek tubuh akan mengikat enzim asetilkolinesterase (AChE), sehingga AChE menjadi infaktif dan terjadi akumulasi asetilkolin. Asetikolin bekerja pada ganglion disimpatik dan parasimpatik, reseptor parasimpatik, neuro-muscular junction, neuro-transmitter sel-sel saraf dan medulla kelenjar suprarenal. Keadaan ini akan menimbulkan efek yang luas. Depolarisasi yang menetap pada otot-otot rangka, sehingga mula-mula terjadi fasikulasi yang disusul dengan blok neuromuskular dan paralisis. $^{2}$ Dalam kasus ini keracunan insektisida golongan organofosfat menyebabkan peningkatan kecepatan rigor mortis dan dimana terjadinya deplesi ATP dan peningkatan reseptor ACh sehingga kontraksi otot terjadi secara terus menerus (tanpa relaksasi). ${ }^{7,8,20}$

Penelitian ini kami menemukan bahwa rerata waktu mulai melemas pada kelompok kontrol (600,20 menit) lebih tinggi daripada kelompok perlakuan $(469,20$ menit), secara statistik terdapat perbedaan yang bermakna $(p<0,05$ atau $p=0,000)$. Hal ini menunjukkan bahwa terdapat perbedaan waktu terbentuk rigor mortis antara kelompok kontrol (kelinci yang tidak diberikan diazinon) dengan kelompok perlakuan (kelinci yang diberikan organofosfat). Dalam teori, Pada 12 jam setelah kekakuan maksimal (24 jam postmortem) kaku jenazah sudah tidak ada lagi. $^{2}$ dan pada teori yang lain mengatakan beberapa hari selanjutnya, kaku mayat secara bertahap berkurang akibat proteinprotein yang terlibat dalam kompleks rigor mortis mulai terurai. ${ }^{7,8}$ Pada kelinci mungkin lebih cepat, hal ini mungkin karena luas penampang tubuh kelinci yang lebih kecil dibandingkan manusia, sehingga, efek rigor mortis lebih cepat menghilang (keadaan mulai melemas). Hasil dari penelitian ini (tabel 5) menunjukkan bahwa kisaran waktu keadaan mulai melemas terbentuk pada kelompok kontrol (594-603 menit) lebih tinggi dibandingkan dengan kisaran waktu keadaan mulai melemas pada kelompok perlakuan yang mati akibat intoksikasi organofosfat (455-485 menit). Secara teori, ini disebabkan efek dari intoksikasi organofosfat yang menghambat AChE sehingga produksi ACh secara terus menerus, dan mempengaruhi otot dalam pengahsilan ATP. Penggunaan ATP secara terus menerus, dalam beberapa jam akan habis, sehingga keadaan rigor mortis mulai melemas. Semakin cepat terjadinya rigor mortis, semakin cepat pula terjadinya deplesi ATP dan terjadi relaksasi (keadaan mulai melemas). ${ }^{8,12,15,16,21}$ 


\section{SIMPULAN}

Berdasarkan hasil penelitian dan bahasan dapat disimpulkan bahwa waktu terbentuk rigor mortis dan waktu mulai melemas lebih singkat pada kelinci dengan intoksikasi organofosfat dibandingkan kontrol.

\section{Saran}

Sebaiknya dilakukan penelitian lanjut dengan menggunakan alat ukur untuk menilai rigor mortis.

\section{DAFTAR PUSTAKA}

1. Howard C, Adelman M. Establishing the Time of Death. In: Forensic Medicine. New York: Infobase Publishing, 2007; p. 20-6.

2. Budiyanto A, Widiatmika W, Sudiono S, Winardi T, Abdul Mun'in, Sidhi, et al. Ilmu Kedokteran Forensik. Jakarta; FKUI, 1997; p. 28-9, 121-8.

3. Moeloek NF. [cited 2015 Sep 17]. Available from:

www.depkes.go.id/resources/download/ info-publik/Renstra-2015.h.17.

4. WHO. in collaboration with United Nation Environment Programme. Public Healthy Impact of Pesticides Used in Agriculture. Geneva: 1990.

5. Gadoth N, Fisher A. Late onset of neuromuscular block in organophosphate poisoning. New York: Interscience Publication 1978. [cited 2015 Sep 17]. Available from: medind.nic.in.

6. Winny, Suwindoro. Pengaruh Pestisida Terhadap Lingkungan. Lingkungan dan pembangunan. 1993;13:233-46.

7. Sherwood L. Fisiologi Manusia; dari Sel ke Sistem (6th ed). Jakarta: EGC, 2012; p. 266-71, 288-9.

8. Guyton AC, Hall JE. Buku Ajar Fisiologi Kedokteran (11th ed). Jakarta: EGC, 2012; p. 86.

9. Sutikno S. Dasar - Dasar Insektisida dan Dampak Penggunaannya. Jakarta: Gramedia Pustaka Utama, 1992.

10. Jaga, Kushi, Dharmani, Chandrabhan. Sources of Exposure to and Public Health Implications of Organophosphate Pesticides. Rev
Panam Salud Publica/Pan Am J Public Health. 2003;14(3).

11. Monica E. Bahaya Bahan Kimia pada Kesehatan Manusia dan Lingkungan. Jakarta: EGC, 2005.

12. Grob D, Harvey AM. The effects and treatment of nerve gas poisoning. Am J Med. 1953;14:52-63.

13. Milby TH. Prevention and management of organophosphate poisoning. JAMA. 1971;216:2131-3.

14. Raii, Mariana. Toksikologi Pestisda dan Penanganan Akibat Keracunan Pesisida. Media Litbang Kesehatan. 2007;XVII(3).

15. Calvert G, Karnik M, Mehler J, Beckman L, Morrissey J, Sievert B, et al. Acute pesticide poisoning among agricultural workers in the United States. 1998-2005. American Journal of Industrial Medicine. 2008;51 (12):88398.

16. Ecobichon DJ. Toxic effects of pesticides. In: Klaassen CD. Casarett and Doull's Toxicology: The Basic Science of Poisons (6th ed). McGraw-Hill Professional, 2001. [cited 2015 Sep 17]. Available from: murdercube.com

17. International Code of Conduct on the Distribution and Use of Pesticides. Food and Agriculture Organization of the United Nations. Rome, 2003.

18. Asti, Yodenca. Faktor-Faktor Yang Berhubungan dengan Keracunan Insektisida Organofosfat, Karbamat Dan Kejadian Anemia pada Petani Hortikultura Di Desa Tejosari Kecamatan Ngablak Kabupaten Magelang [Tesis]. Semarang: Fakultas Kesehatan Masyarakat Universitas Diponegoro; 2008.

19. Wiliiams P. Properties and Effects of Pesticides In: Principle of Toxicology. New York: Wiley, 2000; p. 345-51.

20. Afriyanto. Kajian Keracunan Pestisida Pada Petani Penyemprot Cabe Di Desa Candi Kecamatan Bandungan kabupaten Semarang [PhD thesis]. Semarang. Universitas Diponegoro; 2008.

21. Hodgson E. A Textbook of Modern Toxicology. New Jersey: John Wiley \& Sons, 2004; p. 54-64. 